\title{
Influence of Geometric Parameters on the Average Outlet Velocity of the Bladeless Fan
}

\author{
Doğukan Akgöl ${ }^{1 *}$, Şahin Yavuz ${ }^{2}$ \\ ${ }^{1 *}$ Dokuz Eylül University, The Graduate School of Natural and Applied Sciences, İzmir, Turkey, (ORCID: 0000-0002-0452-8932), dogukan.akgol@deu.edu.tr \\ ${ }^{2}$ Dokuz Eylül University, Faculty of Engineering, Department of Mechanical Engineering, İzmir, Turkey, (ORCID: 0000-0001-9007-772X), sahin.yavuz@,deu.edu.tr
}

(1st International Conference on Applied Engineering and Natural Sciences ICAENS 2021, November 1-3, 2021)

(DOI: 10.31590/ejosat.1022116)

ATIF/REFERENCE: Akgöl, D., \& Yavuz, Ş. (2021). Influence of Geometric Parameters on the Average Outlet Velocity of the Bladeless Fan. European Journal of Science and Technology, (28), 1501-1507.

\begin{abstract}
After the development of bladeless fans, design considerations about the fan models have been changed. However, developing an optimum bladeless fan based on geometric parameters is essential due to their possible future applications. In this study, the effect of three geometric parameters such as Coanda surface curvature, bladeless fan cross-section thickness and nozzle outlet gap on the performance of different bladeless fan designs are investigated. These unique features have a significant impact on the bladeless fan's performance. This research uses numerical simulations to get a better understanding of the effects of these three parameters on the performance and the average outlet velocity of bladeless fans. To observe the velocity distribution of the air inside the bladeless fan chamber and average outlet velocity magnitude at the nozzle outlet, ANSYS-Fluent software is used to do three-dimensional numerical simulations. Based on a simplified bladeless fan concept, different bladeless fan cross-sections are designed by changing these three parameters and CFD simulations conducted on these models. It is found that the nozzle outlet gap has the strongest effect on the outlet velocity magnitude of the fan as expected. On the other hand, the other two parameters that choose have significant effects on flow distribution and aerodynamic performance of the bladeless fan. Fan cross-section thickness is a crucial parameter for the internal flow turbulence characteristics inside the bladeless fan ring. This research will be valuable in improving the performance of bladeless fans and will give useful ideas about optimum fan design.
\end{abstract}

Keywords: Bladeless fan, Aerodynamic performance, Computational fluid dynamics (CFD), 3D numerical simulation, Coanda surface.

\section{Pervanesiz Fanın Ortalama Çıkış Hızına Geometrik Parametrelerin Etkisi}

$\ddot{O} \mathbf{z}$

Pervanesiz fanların geliştirilmesinden sonra, fan modelleriyle ilgili dizayn düşünceleri değişti. Bununla birlikte, geometric parametreler üzerinden optimum bir kanatsız fan geliştirmek, gelecekteki olası uygulamaları için kaçınılmazdır. Bu çalışmada, Coanda yüzey eğriliği, kanatsız fan kesit kalınlığı ve nozul çıkışı açıklığı gibi üç geometrik parametrenin farklı pervanesiz fan tasarımlarının performansına etkisi araştırılmıştır. Bu araştırma, pervanesiz fanların performansı ve ortalama çıkış hızı üzerindeki bu üç parametrenin etkilerini daha iyi anlamak için sayısal simülasyonlar kullanır. Pervanesiz fan kesit boşluğu içindeki havanın hız dağılımını ve nozul çıkışındaki ortalama çıkış hızı büyüklüğünü gözlemlemek amacıyla üç boyutlu sayısal simülasyonlar yapmak üzere ANSYS-Fluent yazılımı kullanılmıştır. Basitleştirilmiş pervanesiz fan konsepti üzerinde, bu üç parametre değiştirilerek farklı pervanesiz fan kesitleri tasarlanmış ve bu modeller üzerinde CFD simülasyonları gerçekleştirilmiştir. Nozul çıkışı aralığının, beklendiği gibi fan çıkışı hızı üzerinde en güçlü etkiye sahip olduğu bulunmuştur. Öte yandan, seçilen diğer iki parametrenin pervanesiz fanın akış dağılımı ve aerodinamik performansı üzerinde önemli etkileri vardır. Fan kesiti genişliği, pervanesiz fan halkası iç akış türbülansı karakteristiği için çok önemli bir parametredir. Bu araştırma, pervanesiz fanların performansını iyileştirmede değerli olacak ve optimum fan tasarımı hakkında faydalı fikirler verecektir.

Anahtar Kelimeler: Pervanesiz fan, Aerodinamik performans, Hesaplamalı akışkanlar mekaniği (HAM), Üç boyutlu nümerik simülasyon, Coanda yüzeyi.

* Corresponding Author: dogukan.akgol@deu.edu.tr 


\section{Introduction}

Nowadays, bladeless fans are widely used in areas such as ventilation and cooling systems and gaining significant popularity. Compared to traditional radial and axial fans, the bladeless fans stated in other words air multipliers have some advantages especially like aerodynamic efficiency and security concerns. Air multipliers could multiply volumetric flow rate of air intake, nearly 15 times depends on geometric design, by sucking stationary air from back of the fan. Besides these advantages of air multipliers, the commercial products that are designed to use in domestic applications are easier to clean and hidden blades make bladeless fans safer for kids compared to traditional fans.

The key difference between bladeless and conventional fans are the doubling intake air flow and the lack of a visible impeller. People would prefer bladeless fans due to their better performance and quality, and their health and comfort benefits. Bladeless fans growing popularity led to a limited increase in related studies. An increase in the studies will lead to the emergence of various innovations associated with bladeless fan technology in the future. At present axial and centrifugal fans have been the focus of numerous experimental and numerical studies. However, there are limited studies on Bladeless fans in the literature. The focus of numerous experimental and numerical studies has been axial and centrifugal fans. Lin and Huang used numerical simulations to analyze and design a forward-curved centrifugal fan [1]. Mohaideen used the finite element method to redesign a weightoptimized axial fan blade and reduced 18.5 percentage of the fan blade mass by optimizing the blade thickness parameter using stress analysis [2].

Coanda effect is the key point behind the design. The Coanda effect has been the area of study of several studies in various areas of research [3]. Few researchers have focused on their studies at the Coanda surface and other parameters of the bladeless fan in the past. $\mathrm{Li}$ et al. reported the influence of Coanda surface curvature of the bladeless fan on its performance [4]. Moreover, Jafari et al. [5] studied effects of more than one parameter. The total effects of five parameters, namely, bladeless fan crosssection height, outlet slit thickness, outlet flow angle relative to the fan axis, etc. However, many studies related to the bladeless fan design and performance evaluation performed for the commercial bladeless fans designed for domestic use.

In this study, instead of focusing on a single parameter, the total effect of three geometric cross- sectional parameters of bladeless fan such as fan cross-section thickness, the nozzle gap and Coanda curvature on average outlet velocity of the fan. The main goal of this work is to ensure that the flow is developing as laminar as possible while trying to maximize the speed. The increase in the nozzle outlet velocity also increases the amount of stationary air sucked from the environment of bladeless fan. High velocity flow at the bladeless fan nozzle is revealing a lowpressure area. Stationary air outside the fan has high pressure and this pressure difference between inside and outside of the fan induces stationary air to the other side of the bladeless fan ring.

As is known, unlike the studies using fan models with standard airfoil cross-sections like NACA 0012 [1] and Eppler 473 [5], in this study, a specially designed cross-section has been used in consideration of Computational Fluid Dynamics (CFD) analyses to maximize the outlet air velocity.
The turbulence inside the bladeless fan is modeled by the realizable $\mathrm{k}-\varepsilon$ turbulence model. After several $\mathrm{k}-\omega$ turbulence model simulations with different models, realizable $\mathrm{k}-\varepsilon$ turbulence model was found to be the best fitting method for these models.

\section{Material and Method}

The bladeless fan was designed to maximize the average nozzle outlet velocity and to reduce the inefficiencies due to air vortexes inside the bladeless fan, see Fig. 1. Flow form and distribution were observed through the CFD analyses by ANSYSFluent software. As proposed in this research, these bladeless fan models were designed for small-scale applications in contrast to recent commercial bladeless fan products. These designs to be used in these small-scale applications, play an important role in future usage areas of the bladeless fans.
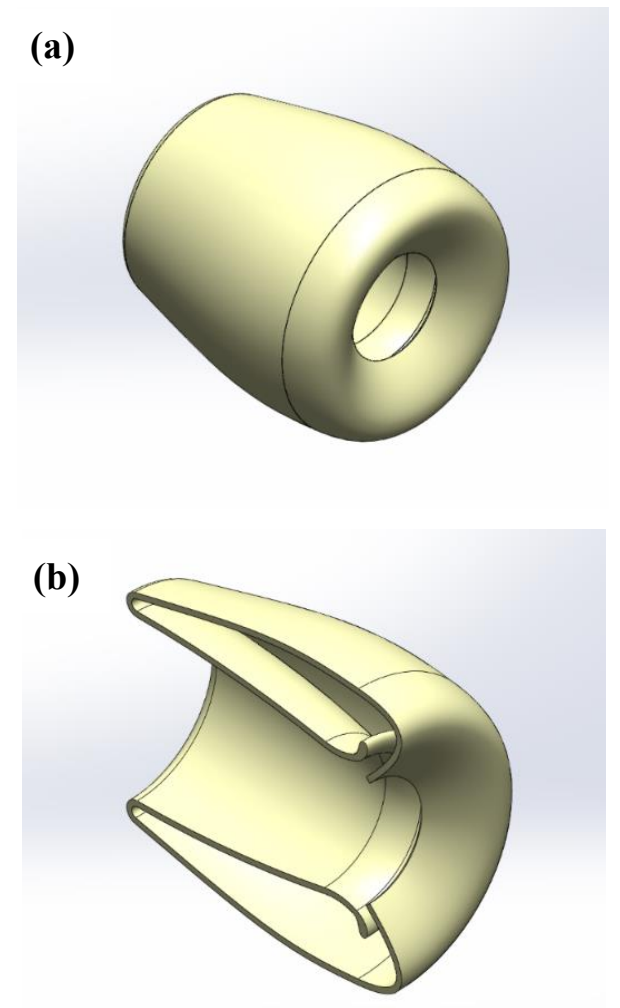

Fig. 1. (a) One of the bladeless fan designs with $98 \mathrm{~mm}$ fan diameter. (b) Bladeless fan cross-section view. 


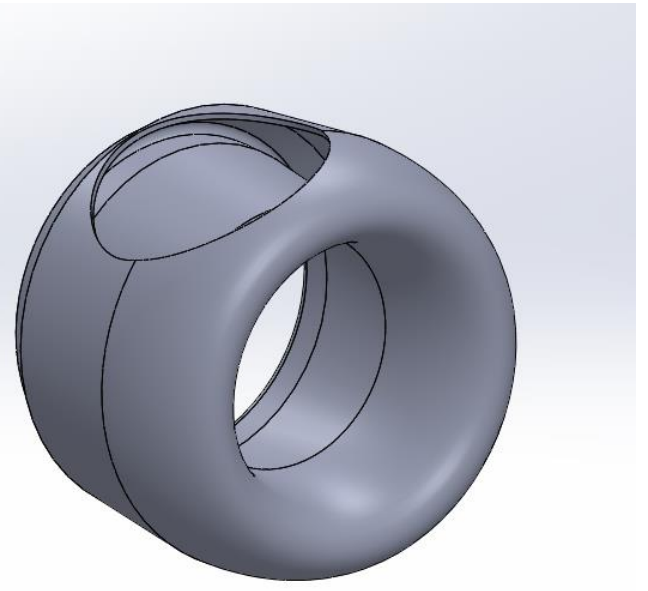

Fig. 2. First model with a single air inlet hole

Firstly, bladeless fans with a single air inlet hole were designed, as seen in Fig. 2. The air stream with a velocity of 40 $\mathrm{m} / \mathrm{s}$ is filled into bladeless fan cross-section from this single hole. As a result of the simulations conducted to observe the internal flow behavior, it was seen that the air is not circulating homogeneously inside the bladeless fan cross-section. Additionally, as shown in Figure 3, too much air vertexes emerging left and right of the inlet symmetrically. Moreover, it can also be observed that there is not enough air coming to the farthest part of the inlet.

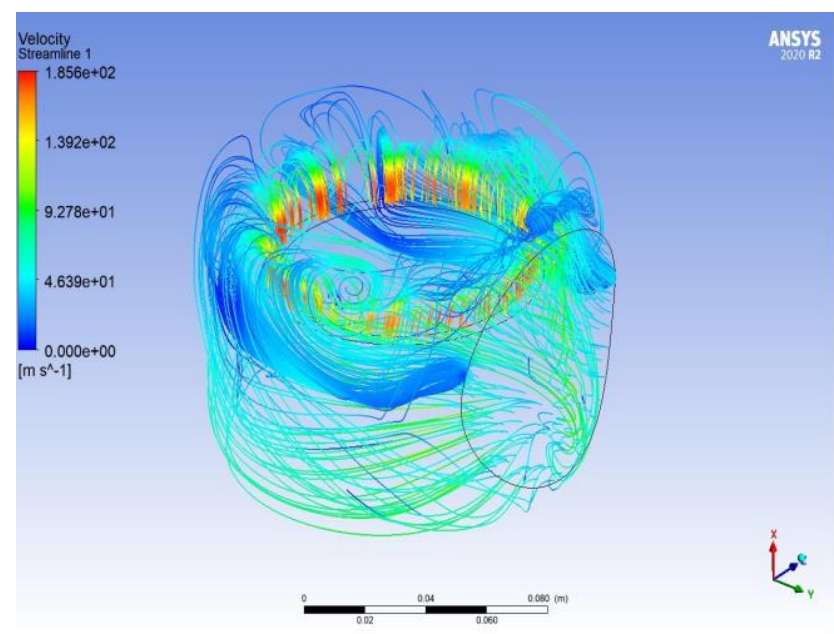

Fig. 3. Air streamline distribution for the first bladeless fan model.

As a result of the analyzes carried out for the first model, average nozzle outlet velocity was obtained as $143.039 \mathrm{~m} / \mathrm{s}$. After the first CFD simulations it was determined that model needs one more symmetric inlet to obtain a more homogeneous distribution by ensuring that the flow reaches the rear parts of the bladeless fan (Figure 4). It was found that the optimal inlet hole diameter for the second model is $60 \mathrm{~mm}$, for each. It was determined that the inlet speed of $40 \mathrm{~m} / \mathrm{s}$ is separated into two to $20 \mathrm{~m} / \mathrm{s}$ for each inlet.

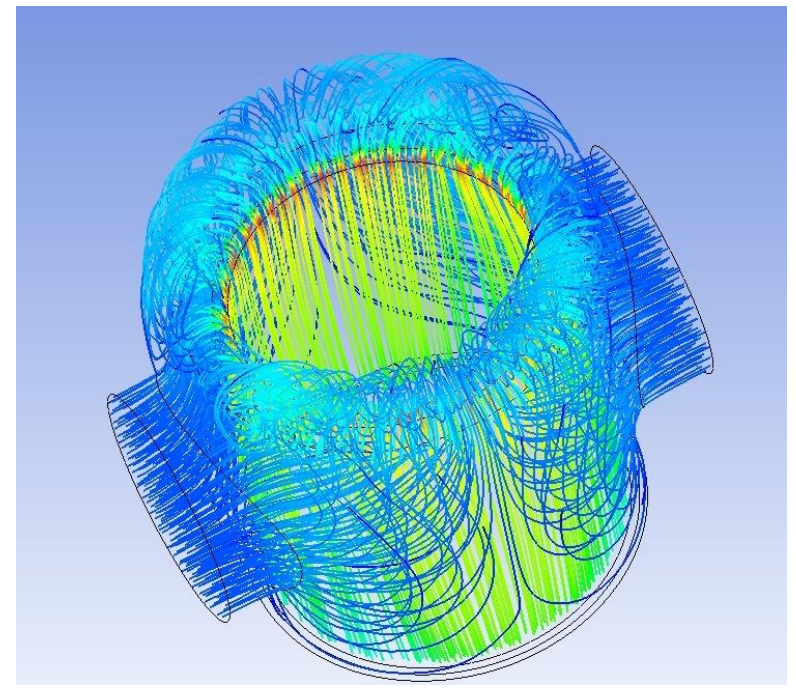

Fig. 4. Second model with two inlets

Another issue discovered through CFD observations was that the inner leading section of the fan cross-section generated turbulence, because of its vertical position, as seen in Figure 5, in the fan ring as it passed the nozzle and affected the bladeless fan performance.

Based on the CFD results and observations about inefficiencies, a new model was developed to extinguish these effects on internal airflow. The thickness and orientation angle of the inner leading section was reduced so that the airflow can pass over leading section without creating turbulence. After the final cross-section was decided at the end of the CFD simulations, four main models.

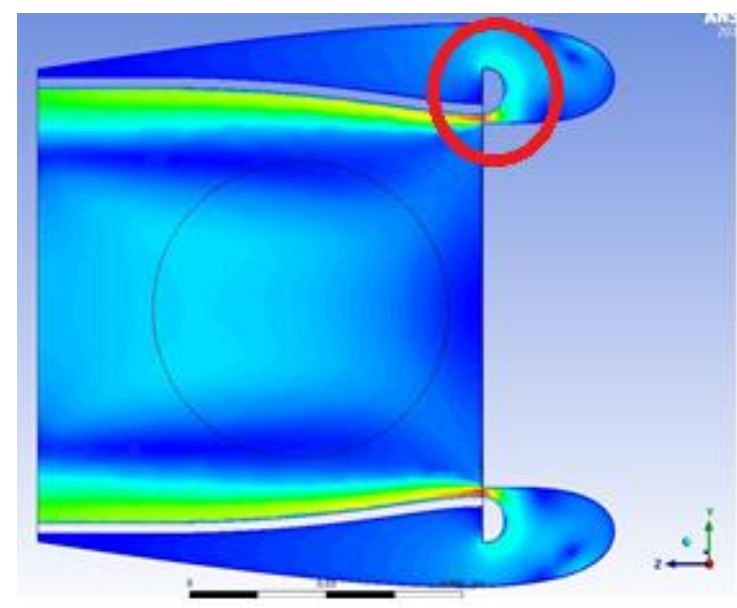

Fig. 5. Inner leading section causing turbulence in air flow

\subsection{Computational Method}

In this work, the realizable $k-\varepsilon$ turbulence model is used to simulate turbulent flow inside the bladeless fan ring. This model was proposed by Shih et al. (1994) as a significant improvement over the standard $k-\varepsilon$ model [6]. After several CFD simulations with different turbulence models like $k-\omega$ turbulence model and standard $k-\varepsilon$ turbulence model, it was decided that the best turbulence model to adopt for this investigation was Realizable $k$ $\varepsilon$ turbulence model with a near wall treatment method of enhanced wall treatment. The SIMPLE algorithm is used for pressure-velocity coupling with second order upwind scheme for 
momentum, turbulent kinetic energy and turbulent dissipation rate.

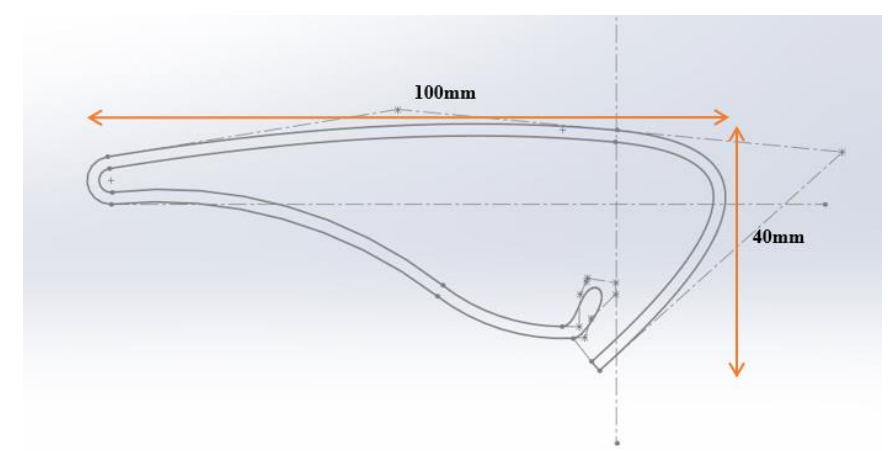

Fig. 6. Overall size of the first prototype.

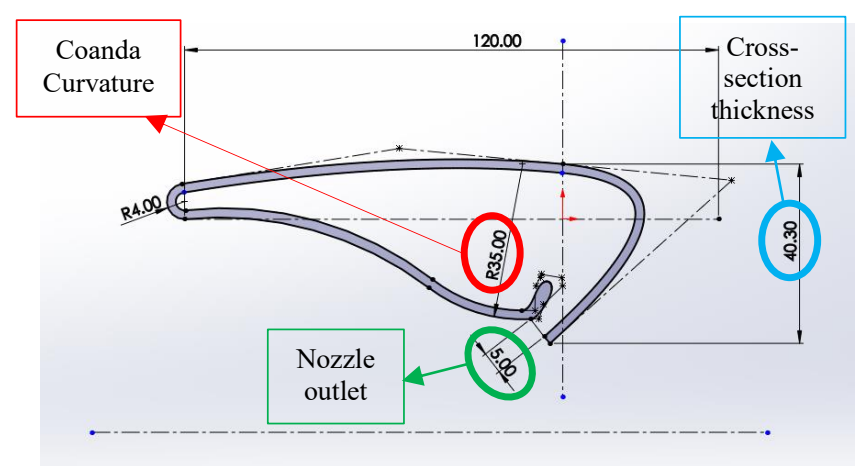

Fig. 7. Coanda surface curvature, nozzle outlet gap and cross-section thickness of the first prototype.

As a result of the observations, four main models were designed to investigate the effect of fan cross-section thickness and Coanda surface curvature parameters on average outlet velocity magnitude. (a)
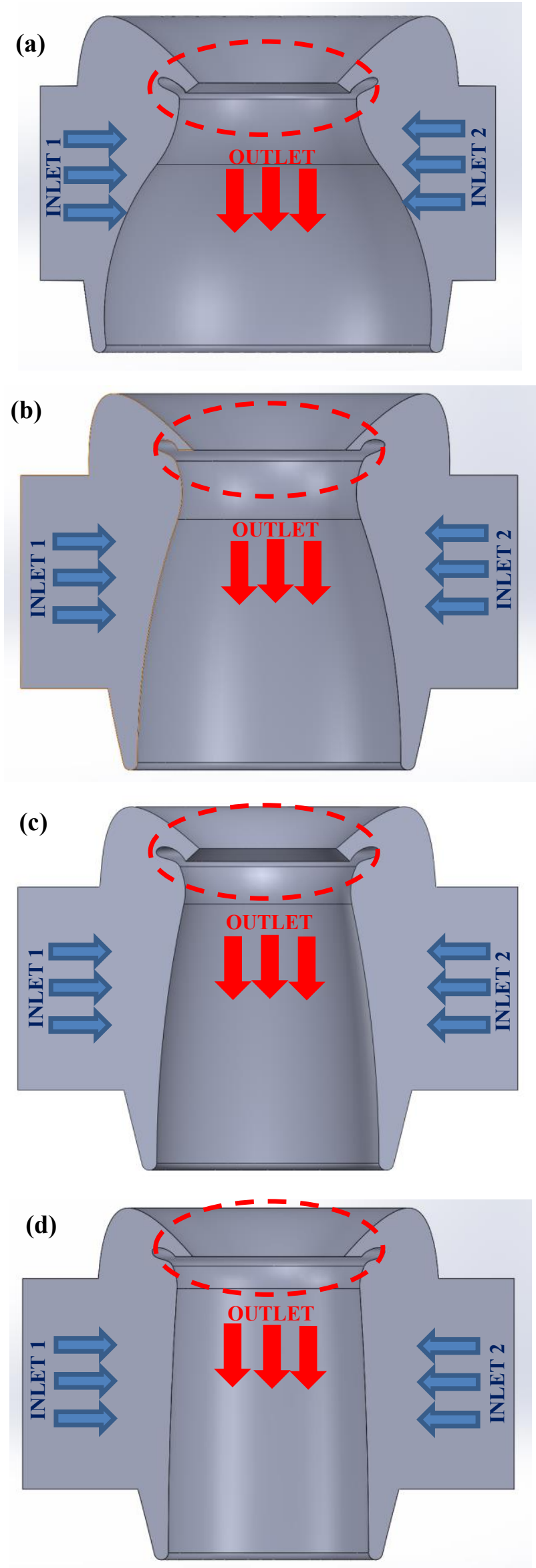

Fig. 8. Final four models; a) Model 1, b) Model 2, c) Model 3 and d) Model 4 after first CFD simulations. 
Four main models with different cross-sectional parameters designed (Figure 8 ) and dimensions of all models are given Table 1.

Table 1. Cross-sectional dimensions table of all four models.

\begin{tabular}{|c|c|c|}
\hline Model & $\begin{array}{c}\text { Cross-Section } \\
\text { Thickness }\end{array}$ & $\begin{array}{c}\text { Coanda } \\
\text { Curvature }\end{array}$ \\
\hline Model 1 (a) & $\mathrm{t}_{1}=31 \mathrm{~mm}$ & $\mathrm{R}_{1}=35 \mathrm{~mm}$ \\
\hline Model 2 (b) & $\mathrm{t}_{2}=26.25 \mathrm{~mm}$ & $\mathrm{R}_{2}=25 \mathrm{~mm}$ \\
\hline Model 3 (c) & $\mathrm{t}_{3}=23.06 \mathrm{~mm}$ & $\mathrm{R}_{3}=20 \mathrm{~mm}$ \\
\hline Model 4 (d) & $\mathrm{t}_{4}=22 \mathrm{~mm}$ & $\mathrm{R}_{4}=15 \mathrm{~mm}$ \\
\hline
\end{tabular}

\subsection{Boundary Conditions}

The main concentration of this study was on geometrical characteristics of bladeless fan, therefore, motor section with an impeller of the fan was not considered and simulated in this study. Instead, the appropriate amount of airflow inlet boundary condition was set to the two inlet sections of every model independently.

Air enters through a $6 \mathrm{~cm}$ diameter cylindrical inlet beneath the ring section of the bladeless fan, as shown in Figure 9. The intake air then travels through a small gap to the fan's annular section, where the cross-section has a specially designed airfoil profile.

In Fig. 9 solid models are representing the extracted volume of air inside the bladeless fan cross-section. In CFD simulations performed in ANSYS-Fluent environment, these extracted air volumes were used. The boundary conditions are considered as velocity inlet for INLET 1 and INLET 2 faces and as pressure outlet for OUTLET face. Other faces treated as wall fluid boundary condition. The first CFD analysis was performed to determine the mesh independence of the analysis by using the Model 2.

\subsection{Mesh Independence}

Before simulating case studies and calculation of $\mathrm{y}^{+}$value, according to cells attributed to the bladeless fan, mesh independence of the first simulation is performed to find a suitable cell number. Therefore, eight different mesh sizes from $12 \mathrm{~mm}$ element size to $0.8 \mathrm{~mm}$ cells for the simulation of Model 2 fan with a diameter of $101 \mathrm{~mm}$ and thickness of $5 \mathrm{~mm}$ nozzle outlet, have been used, as shown in Table 2 .

Table 2. The results obtained from mesh independence analysis of Model 2.

\begin{tabular}{|c|c|c|c|}
\hline $\begin{array}{c}\text { Analysis } \\
\text { Number }\end{array}$ & $\begin{array}{c}\text { Mesh } \\
\text { Element } \\
\text { Size }(\mathbf{m m})\end{array}$ & $\begin{array}{c}\text { Number of } \\
\text { cells }\end{array}$ & $\begin{array}{c}\text { Nozzle } \\
\text { Outlet } \\
\text { Velocity }(\boldsymbol{m} / \mathbf{s})\end{array}$ \\
\hline $\mathbf{1}$ & 12 & 503132 & 229.8884 \\
\hline $\mathbf{2}$ & 8 & 505508 & 231.9662 \\
\hline
\end{tabular}

\begin{tabular}{|c|c|c|c|}
\hline $\mathbf{3}$ & 7 & 505542 & 233.4112 \\
\hline $\mathbf{4}$ & 6 & 509768 & 234.6435 \\
\hline $\mathbf{5}$ & 4 & 529440 & 236.892 \\
\hline $\mathbf{6}$ & 2 & 736811 & 238.2792 \\
\hline $\mathbf{7}$ & 1 & 1999827 & 239.0117 \\
\hline $\mathbf{8}$ & 0.8 & 3188485 & 238.7405 \\
\hline
\end{tabular}

\section{Mesh Independence}

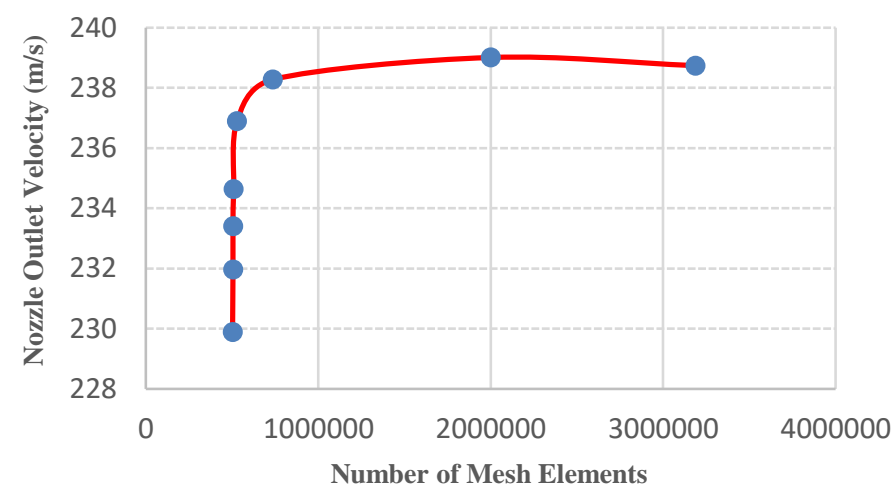

Fig. 9. Mesh independence analysis with eight different mesh sizes.

The velocities at the nozzle outlet are compared for the eight different mesh sizes (for inlet airflow velocity of $20 \mathrm{~m} / \mathrm{s}$ at each inlet), as shown in Figure 9.

We can see that the mesh element number of 736811 elements or more is suitable for the analysis. Since the model geometry does not change significantly, this mesh number and element size were used for all other analyzes with other models.

\section{Results and Discussion}

\subsection{CFD Simulation Results}

Series of CFD simulations carried out for four models, were designed as shown in Figure 9. The first analysis was performed for the first model with the previously determined mesh size.

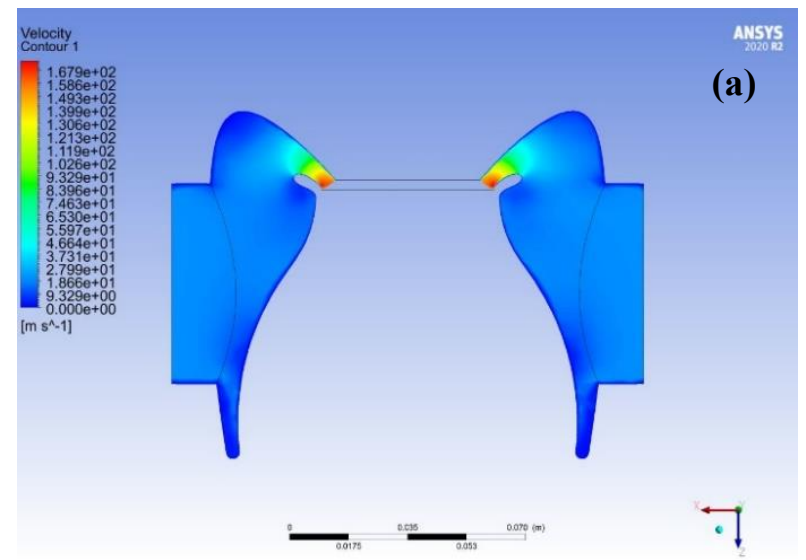




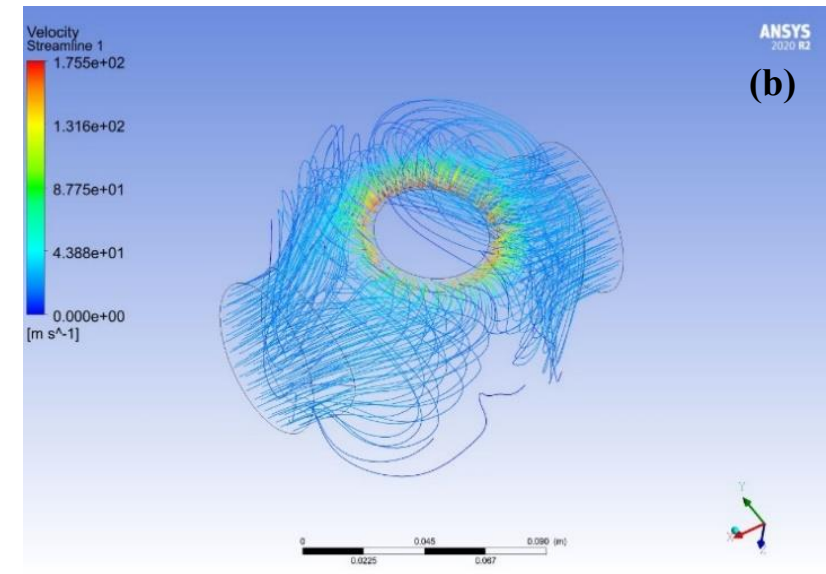

Fig. 10 (a) Velocity contour inside the fan ring. (b) Airflow streamlines for Model 1.

It can be seen from Figure 10(a) the maximum velocity at the nozzle outlet is almost $168 \mathrm{~m} / \mathrm{s}$. Also, average outlet velocity for the Model 1 is obtained as $154.07 \mathrm{~m} / \mathrm{s}$. The magnification factor between inlet airflow velocity and outlet airflow velocity can be calculated as approximately 3.8517 . It can be seen from the CFD data in Figure 10 that designed model makes the airflow velocity increase almost 4 times. It should be noted that the average $\mathrm{y}+$ value of the Model 1 is calculated as 63.281.

With the improvements made on the first model, the second model has been designed to maximize the outlet velocity.

Model 2 was analyzed using the same mesh size and boundary conditions with Model 1 . The second prototype has a lover Coanda surface curvature with a radius of $25 \mathrm{~mm}$ and a cross-section thickness of $26.25 \mathrm{~mm}$.

As seen in the CFD simulation results of the second prototype, shown in Figure 11, circulation at the inner leading section reduced and the outlet velocity increased significantly. Maximum outlet velocity is $277.8 \mathrm{~m} / \mathrm{s}$ and the average outlet velocity is calculated as $254.334 \mathrm{~m} / \mathrm{s}$. Magnification factor between the inlet airflow and the outlet airflow can be calculated as almost 6.35 . The second prototype can accelerate the airflow up to 6.35 times.

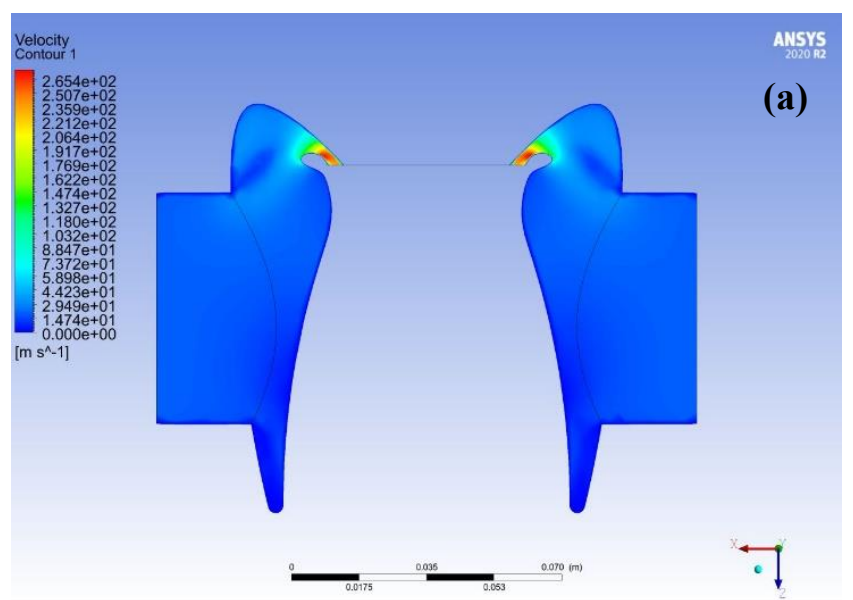

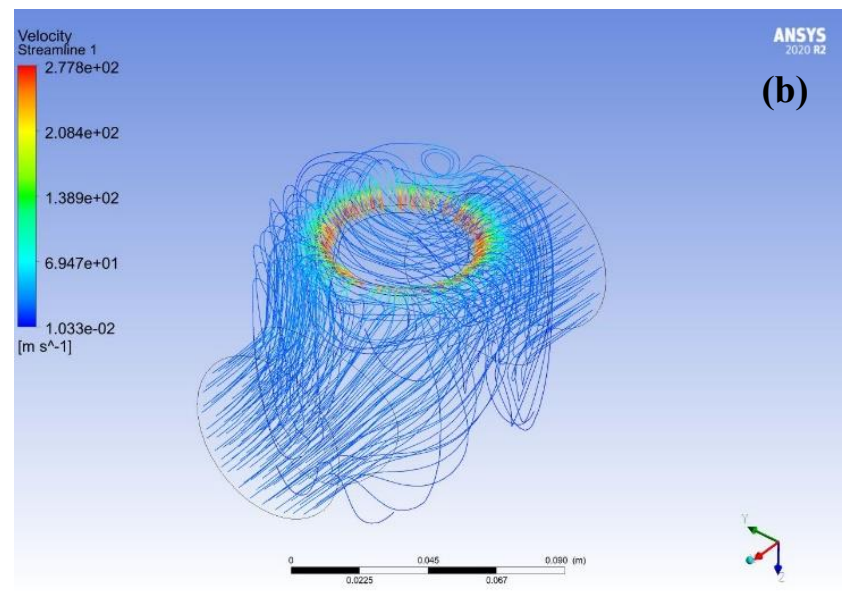

Fig. 11. CFD simulation of the second prototype bladeless fan. a) Velocity contour b) Velocity streamlines. The airflow magnification increased.

The other two models were simulated under the same conditions. In the third prototype, Coanda curvature and crosssectional thickness were adjusted to $20 \mathrm{~mm}$ and $23.06 \mathrm{~mm}$ respectively. This design change caused the outlet velocity to decrease again to $157 \mathrm{~m} / \mathrm{s}$. This can be caused by a reduction in cross-sectional air capacity of the fan ring. The simulation results of the third model can be seen in Figure 12.

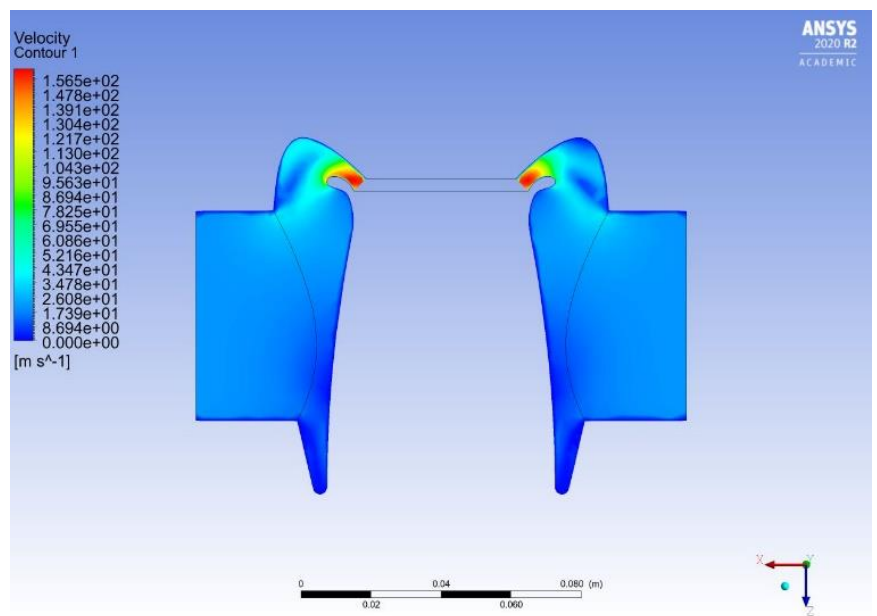

Fig. 12. Velocity contour of the third prototype. Average Outlet velocity decreased to $157 \mathrm{~m} / \mathrm{s}$.

Finally, a low curvature to Coanda surface was implemented for the fourth design. Theoretically when a surface has a curvature, the Coanda effect in airflow increased. The Coanda effect causes fluid to flow more freely along the surface than on a flat surface [7]. Therefore, this low curvature at the Coanda surface results decrease in the Coanda effect. 

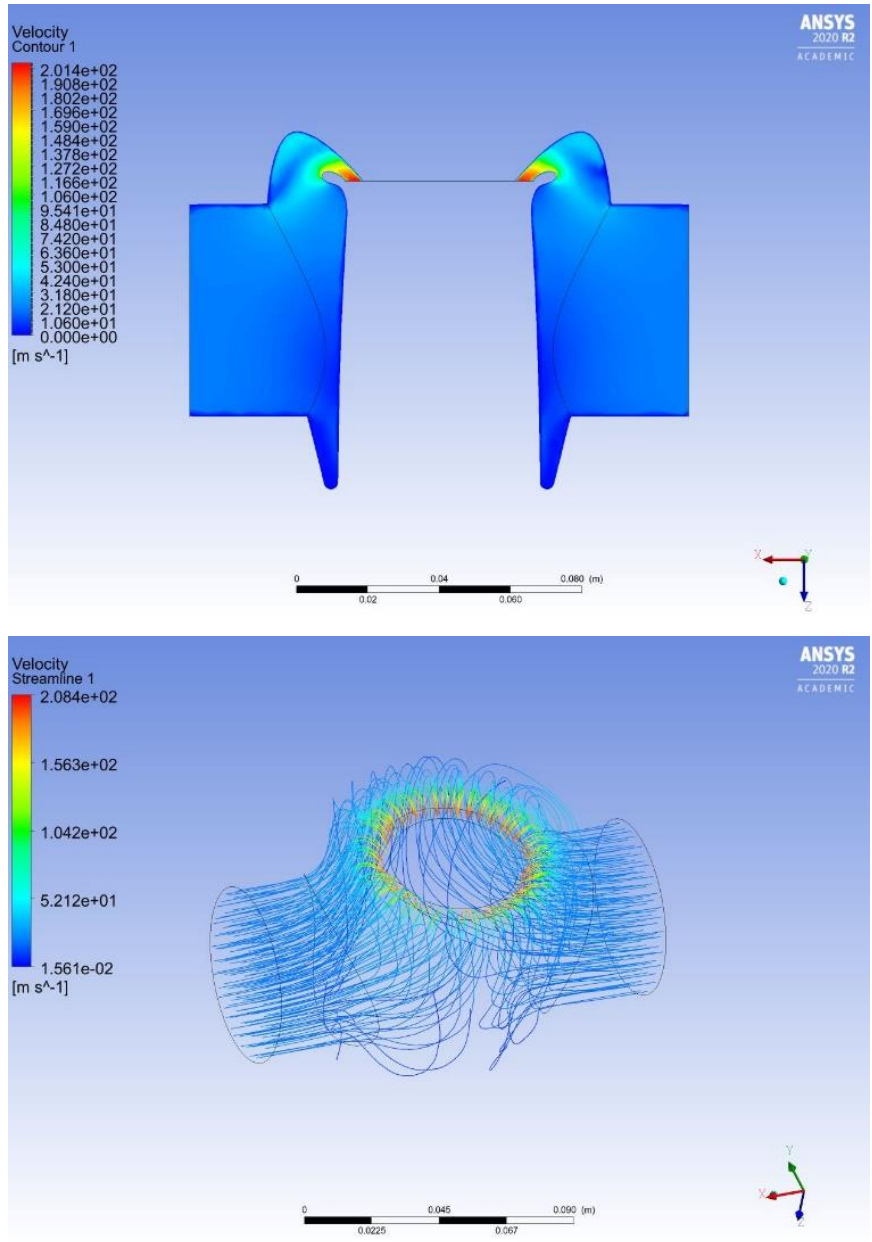

Fig. 13. The velocity distribution of Model 4 inside the ring. Average outlet velocity increased according to Model 3.

The average velocity outlet of the fourth prototype has increased to $199.47 \mathrm{~m} / \mathrm{s}$ and maximum outlet velocity has increased to $206.41 \mathrm{~m} / \mathrm{s}$ as shown in Figure 13. The decrease in the curvature of the Coanda surface and the fan thickness together caused that increase in outlet velocity. All four simulations repeated with a narrower nozzle outlet and as expected, narrowing of the nozzle gap caused an increase in outlet airflow velocity.

In reviewing the literature, there are no sufficient data or enough study done for a bladeless fan of this size. Smaller-scale applications of bladeless fans are essential to increase the usage field. More security and efficiency make these types of fans preferable compared to traditional fans with propellers. This study was designed to observe the effect of geometrical parameters on the outlet velocity for small-scale bladeless fans. The results of this study indicate that there is a relation between geometrical parameters of bladeless fan. The first model has a large curvature at the Coanda surface and has the biggest cross-sectional thickness, but the second model has greater average outlet velocity than first one. Therefore, there is an optimum design between Model 1 and Model 4 to maximize the outlet velocity. It should be noted that this study only exhibits the internal flow effects and at future works these simulations can be combined with external flow simulations. Bladeless fans not only accelerate inlet air, but also induce the outside stationary air and create up to 15 times more airflow depending on the geometry [8].

\section{Conclusions and Recommendations}

Design considerations for fan models have evolved since the development of bladeless fans. However, because of its possible future applications, building an optimal bladeless fan based on geometric characteristics is essential. The effect of three geometric parameters on the performance of several bladeless fan designs is investigated in this research, such as, bladeless fan cross-section thickness, nozzle outlet gap and Coanda surface curvature. This study has shown that there is a relation between these three parameters which should be optimized to maximize outlet velocity. The simulation results of Model 1, Model 2 and Model 3 indicate that the increase in Coanda curvature or in crosssectional thickness does not always come with an increase in average outlet airflow velocity. The current findings add to a growing body of literature on about small-scale bladeless fans. This research has thrown up many questions in need of further investigation. It would be interesting to assess the effects of all geometrical parameters with stationary outside air to see the inducement effects of the bladeless fan. Thus, the total active and passive air flow can be observed and can create ideas and questions for future studies. The findings of this study have several important implications for future practice about smallscale bladeless fan designs.

\section{References}

[1] Lin, S. C., \& Huang, C. L. (2002). An integrated experimental and numerical study of forward-curved centrifugal fan. Experimental thermal and fluid science, 26(5), 421-434.

[2] Mohaideen, M. M. (2012). Optimization of backward curved aerofoil radial fan impeller using finite element modelling. Procedia engineering, 38, 1592-1598.

[3] Drăgan, V. (2012). A New mathematical model for Coandă effect velocity approximation. INCAS Bull, 4, 85-92.

[4] Li, G., Hu, Y., Jin, Y., Setoguchi, T., \& Kim, H. D. (2014). Influence of Coanda surface curvature on performance of bladeless fan. Journal of thermal science, 23(5), 422-431.

[5] Jafari, M., Afshin, H., Farhanieh, B., \& Sojoudi, A. (2016). Numerical investigation of geometric parameter effects on the aerodynamic performance of a Bladeless fan. Alexandria Engineering Journal, 55(1), 223-233.

[6] Shih, T. H., Liou, W. W., Shabbir, A., Yang, Z., \& Zhu, J. (1995). A new k-epsilon eddy viscosity model for high Reynolds number turbulent flows. Computers \& fluids, 24(3), 227-238.

[7] Rašuo, B., \& Mirkov, N. (2014). On the possibility of using Coanda Effect for Unmanned Aerial Vehicles-a numerical investigation. PAMM, 14(1), 627-628.

[8] GAMMACK P D, NICOLAS F, SIMMONDS K J. "Bladeless fan, in Patent Application" US Patent 2009/0060710Al. United States, 2009. 